\title{
Contribuição para uma nova leiturA do texto teatral
}

\author{
Vera Casa Nova \\ Elvina Maria Caetano Pereira \\ UFMG
}

\begin{abstract}
RESUMO
Esse artigo apresenta uma proposta de leitura que tem como base os princípios teóricos da Análise do Discurso e da Semiótica Teatral. Parte da distinção entre teatro, literatura dramática e teoria teatral e vê como objeto da crítica teatral, por sua estreita relaçāo com a literatura, aquilo que denominamos literatura dramática. O teatro proposto por Grotowski é visto como um conceito em cena, na relação entre o ator e o espectador, mediada ou não por um texto. A partir da discussão levantada por Searle sobre o estatuto lógico do discurso ficcional, dois importantes conceitos são definidos: o de teatro de representação e o de teatro de atuação.
\end{abstract}

\section{PALAVRAS - CHAVE}

análise do discurso e teatro; mise-en-scène e significação

Nossa proposta, ao iniciarmos esta reflexão, foi a inserção de alguns conceitos da Análise do Discurso sobre a linguagem teatral, especificamente seu texto e crítica. Partimos, então, de alguns pressupostos da Teoria dos Atos de Fala, tendo em vista as questões de sentido que a Semiótica Teatral nos possibilita ver.

A Análise do Discurso é ainda embrionária e, na maior parte das vezes, concerne à análise do que denominamos "literatura dramática". Existe uma grande lacuna no que se refere ao estudo do discurso veiculado na e pela cena ou, em outras palavras, do teatro-emato. Em Expressão e significado, Searle trava uma discussão - trabalhando com alguns conceitos como os de metáfora, discurso figurado, mentira e ficção - que abre caminho, no nosso entendimento, para uma questão de suma importância: a função do teatro em nossa sociedade. Mais especificamente no capítulo que trata do "Estatuto lógico do discurso ficcional", Searle discute o uso sério da linguagem através dos discursos ficcionais:

(...) atos de fala sérios (isto é, não ficcionais) podem ser transmitidos por textos de ficção, mesmo que o ato de fala transmitido não esteja representado no texto. Quase todas as obras de ficção importantes transmitem uma ou mais "mensagens", que são transmitidas pelo texto mas não estão no texto. (...) [como] um autor transmite um ato de fala sério através da realização dos atos de fala fingidos que constituem a obra de ficçāo. ${ }^{1}$

\footnotetext{
${ }^{1}$ SeARle. Expressão e significado, p.119. Grifos nossos.
} 
Para Grotoswski, a função do teatro é, mais do que de natureza cultural ou estética, de ordem ética: ele não serve para divertir ou alcovitar o espectador, mas para dizer-lhe a verdade. Em nossa reflexão sobre o funcionamento da linguagem teatral, buscamos perceber como ela, através das elocuções ficcionais presentes no texto dramatúrgico, atua como mecanismo de transmissão de atos de fala sérios. A nossa hipótese é de que o discurso cênico funciona, através de instrumentos próprios da linguagem teatral, da mesma maneira que uma metáfora - na qual o falante diz uma coisa querendo significar outra - ou um ato de fala indireto - no qual o falante diz uma coisa e quer significar, além do que está sendo dito, algo mais - e, nesse sentido, o alcance de sua realização lingüística é similar ao da linguagem ordinária.

É interessante assinalar que o funcionamento da linguagem teatral como mecanismo de transmissão de atos de fala sérios é resultado de uma intencionalidade coletiva que direciona o modo de atuação desse mecanismo, visto que o discurso cênico pode ser - e óe, muitas vezes - utilizado como discurso ficcional: mera representação de uma "história".

A distinção que travaremos não é entre o discurso teatral e o ficcional, nem entre a linguagem teatral e a linguagem ordinária. Trata-se aqui de distinguir entre duas formas de encenação, no interior das quais o próprio discurso cênico encontra maneiras distintas de atuar. A encenação-atuação é oriunda de uma linha específica do pensamento teatral contemporâneo que, tendo como seus maiores expoentes Artaud, Grotowski e Peter Brook, homens de teatro de influência incontestável para a atual produção cênica mundial, utiliza, ao nosso ver, a linguagem teatral como mecanismo de transmissão de atos de fala sérios. A produção teatral contemporânea, no entanto, provém de tendências muito diversas e, até mesmo, contrárias. Em razão disso travaremos, em nosso estudo, a distinção entre essa linha de criação cênica e a linha tradicional do teatro - de caráter mimético e baseada, sobretudo, no texto escrito - que denominamos Teatro de Representação. O chamado "teatro tradicional" utiliza, sobretudo, a encenaçãorepresentação, cujo discurso cênico, justamente por esse caráter mimético, é considerado ficcional.

\section{O estatuto do texto no discurso teatral}

Questões relativas à presença do texto na encenação e aos elementos constituintes do discurso cênico vêm sendo amplamente discutidas por alguns dos maiores pensadores do teatro, como Artaud e Grotowski. Para Artaud, a decadência do teatro ocidental bem como de toda a cultura - deve-se ao lugar de honra que tem o discurso verbal no seu interior: o texto é uma amarra na qual se prende a linguagem teatral. $O$ uso da linguagem verbal, em Artaud, é calcado no poder que elas têm de, concretamente, atingir a alma e o corpo do espectador. Para ele, essa performatividade da palavra não está ligada ao seu significado, mas à sua modulação, ritmo e vibração, ou seja, à sua existência quase física, à sua materialidade:

se relacionarmos as palavras com os movimentos físicos que lhes deram origem, se o aspecto lógico e discursivo da palavra desaparecer sob seu aspecto físico e afetivo, isto é, se as palavras ao invés de serem consideradas apenas pelo que dizem gramaticalmente falando forem ouvidas sob seu ângulo sonoro, sejam percebidas 
como movimentos, e se esses movimentos forem assimilados a outros movimentos diretos e simples tal como existem em todas as circunstâncias da vida e como não existem em quantidade suficiente para os atores em cena, se isso se der a linguagem da literatura se recomporá, se tornará viva. ${ }^{2}$

Para Artaud, as palavras se originam nas ações e reações humanas e, para que o teatro trabalhe com essa situação de troca concreta e intrínseca à vida, é necessário buscar as açōes físicas contidas em todo texto. Desse modo, a sinceridade das ações será buscada por meio dos elementos concretos da encenação teatral e o teatro será aproximado da vida por sua verdade. Considerando-se que a fiç̧ão é o universo do fingimento, como lidar com essa condição de sinceridade que é elemento essencial da linguagem teatral? Em sua teoria teatral, Artaud lança alguns princípios e condições para a realização dessa empreitada, porém, não chega a formular nenhum método.

Grotowski, por sua vez, cria um método rigoroso para o trabalho de diretores e atores. Sua crítica a Artaud deve-se justamente ao que ele denomina "engano de Artaud": ao fazer suas proposições revolucionárias sobre teatro, ele não teria deixado nenhuma técnica concreta que permitisse executá-las. Tudo o que Artaud deixou foram "visões, metáforas".

Para Grotowski, ao contrário, o teatro é um laboratório, um centro de pesquisa cujos limites são marcados por disciplinas científicas afins, como semiologia, lingüística, fonologia, psicologia e antropologia cultural - para a qual se exige uma dedicação absoluta - condição essencial para que se validem objetivamente suas experiências.

Um instituto que se dedica a pesquisas desse tipo deve (...) ser um local de encontros, observaçōes e distilação das experiências recolhidas pelos indivíduos (...). Enbora levando em consideração o fato de que o domínio no qual a nossa atenção está centrada não é científico, (...) tentamos contudo determinar nossos objetivos com a precisão e a conseqüência características da pesquisa científica. ${ }^{3}$

Ele enxerga o teatro não como um fim em si mesmo, mas como um veículo, um caminho para a vida. A condição de sinceridade antevista por Artaud, em Grotowski parte do trabalho exaustivo do ator, do seu questionamento diário, do seu engajamento pessoal no âmbito da arte.

Retiramos do ator aquilo que o prende, mas não lhe ensinamos como criar - por exemplo, cono interpretar Hamlet (...) - pois é precisamente nesse "como" que as sementes da banalidade e dos clichês (...) são plantadas. (...) O ator que trabalha aqui já é um profissional, porque não apenas seu trabalho criativo, mas as leis que o regulam tornaram-se objeto de suas preocupações. ${ }^{4}$

O teatro tem leis objetivas e sua realização só é possível se elas forem respeitadas: assim o encontro - essência do teatro - pode ser atingido. Encontro consigo mesmo - através de um ato total de auto-revelação e desnudamento, em uma espécie de confronto sincero e sem máscaras - com o outro e com o texto:

O Teatro é (...) um encontro entre pessoas criativas. Sou eu, o diretor, que me defronto com o ator, e a auto-revelação do ator me dá a revelaçâo de mim mesmo.

\footnotetext{
${ }^{2}$ ARTAUD. O teatro e seu duplo, p.152. Grifos nossos.

${ }^{3}$ GROTOWSKI. Em busca de um teatro pobre, p.104.

${ }^{4}$ IBIDEM. p.104. Grifos nossos.
} 


\begin{abstract}
Os atores e eu nos defrontamos com o texto. (...) Para o ator e o diretor, o texto do autor é uma espécie de bisturi que nos possibilita (...) encontrar o que está escondido dentro de nós e realizar o ato de encontrar os outros: em outras palavras, transcender nossa solidão. (...) No meu caso, não desejo nem a interpenetração literária nem o tratamento literário, (...) uma vez que o meu campo de ação é o da criação teatral. Para mim, criador de teatro, o importante não são as palavras, mas o que fazemos delas, o que confere vida às palavras inanimadas do texto, o que as transforma em "A Palavra". Vou mais longe: o teatro é uma ação engendrada pelas reações e impulsos humanos, pelos contatos entre as pessoas. Trata-se de um ato tão biológico quanto espiritual. ${ }^{5}$
\end{abstract}

Assim como Artaud, Grotowski percebe a verdade como condição básica para a encenação teatral: a sinceridade dos atores é indispensável para a realização de um teatroarte, que tenha realmente algo a dizer. Se violarmos essa condição de sinceridade, não teremos senão uma representação banal, um teatro-diversão ou um "teatro-literatura". Ele deixa bem explícita, em sua teoria, a dicotomia literatura dramática/teatro e, na distinção que trava, relaciona a literatura à ficção e o teatro à realidade. Para um teórico bem como para o outro, o discurso cênico é "sério": ele funciona como metáfora de uma realidade sobre a qual devemos pensar e questionar, na qual devemos ir a fundo. $O$ teatro tem a função de desvelar o mundo, os indivíduos e as relações que travamos com a realidade. Essa linha de pensamento tem como pressuposto para a criação teatral a atuação, na qual o discurso cênico age como uma metáfora. Quais seriam os traços distintivos entre a atuação e a representação?

\title{
A DIFERENÇA DOS LUGARES:
}

\section{A ENCENAÇĀO-ATUAÇĀO E A ENCENAÇĀO-REPRESENTAÇĀO}

Antes de traçarmos a distinção entre essas duas formas de encenação, gostaríamos de delimitar alguns problemas básicos relativos aos conceitos. Em primeiro lugar, é necessário pensar que, no cenário teatral contemporâneo, coexistem várias tendências e maneiras de pensar a ação teatral e sua função. Além dos pensadores citados, temos ainda que considerar o "Sistema" criado por Stanislavski e a linha estética preconizada por Brecht que, cada qual ao seu modo, questionaram a forma vigente do fazer teatral, representado pelo Teatro Tradicional. Na cena brechtiana, por exemplo, o ator mostra seu personagem e desmascara, ao mesmo tempo, o jogo e a representação: esse é o distanciamento, efeito típico da encenação dialética proposta por Brecht em sua obra. Aqui, a maquinaria teatral é revelada, ela aponta para si mesma, dizendo: "Olhem, isto é teatro. Nāo se deixem iludir". Assim, a relação estabelecida entre a cena e a platéia não é de empatia, mas de consciência crítica e o mecanismo utilizado é mais semelhante à ironia do que à metáfora.

Em segundo lugar, os conceitos de encenação-atuação e encenação-representação serão propostos aqui dentro de uma nova perspectiva de leitura do texto teatral. Tendo em vista outras propostas de leitura da linguagem teatral, definiremos os dois conceitos. Peter Brook, por exemplo, em sua obra El espacio vacío (Brook, 1998), diferencia entre quatro tipos de teatro: o teatro mortal, o teatro sagrado, o teatro tosco e o teatro imediato. Nessa distinção, ele relaciona as linhas mestras do teatro contemporâneo.

\footnotetext{
${ }^{5}$ Grotowski. Em busca de um teatro pobre, p.50. Grifos nossos.
} 
Sua definição de teatro mortal engloba o que, na nossa conceituação, chamamos de teatro de representação. Já o teatro sagrado diz respeito à linha de pesquisa engendrada por Artaud e Grotowski, enquanto o teatro tosco refere-se à encenação dialética de Brecht. E, por fim, ele cunha o termo teatro imediato para descrever a sua própria maneira de lidar com a ação teatral: o teatro é visto, aqui, como acontecimento presente e efêmero, como evento.

Já Grotowski - cuja distinçāo serviu de base para a nossa e é, nesse sentido, bastante semelhante - diferencia o Teatro Pobre do Teatro Rico, assim como distingue o "ator santo" do "ator cortesão". E, finalmente, em terceiro lugar, não podemos deixar de considerar que o teatro tradicional não traz em seu seio nenhuma conceituação dessa natureza: para ele, o teatro tem sempre um caráter mimético e, justamente em virtude dessa característica, é que a linguagem teatral se define.

A partir desses elementos, podemos traçar a dicotomia entre representação e atuação. Para isso, tomaremos, a princípio, os conceitos dicionarizados. O que significa, de fato, "representar"? 1. Re-apresentar, apresentar de novo, presentificar; 2. Fazer o papel de alguém, fingir ser outra pessoa; 3. Figurar, através de uma pintura ou narrativa; 4. Simbolizar, trazer ao espirito ou à mente; 5. Reproduzir; 6. Interpretar um papel ou personagem (em um espetáculo teatral, no cinema etc.). Girard, Ouellet e Rigault definem "representar" como o ato de

tornar presente (ou público) um objeto ausente: toda representação presentifica e substitui uma ação, um objeto, uma pessoa. Essa substituição não faz desaparecer o objeto representado, mas faz coexistir duas presenças: uma direta, concreta, e a outra mediatizada, figurada pela primeira. ${ }^{6}$

Durante uma representação teatral, o público tem, como realidade concreta, os atores, as falas pronunciadas, o cenário, o figurino, a iluminação e outros recursos cênicos. Tudo isso remete a uma realidade simbólica: a um tempo/espaço ficcional, suportado nas convenções teatrais - personagens, fábula, trama narrativa, etc - que envolvem o espectador em uma ilusão cênica na qual, para participar do jogo teatral, é necessário acreditar. Em outras palavras, podemos dizer que representar, para o teatro tradicional, é a função da encenação: ação teatral é mimesis (imitação da vida não como ela é, mas no que tem de mais "nobre"). Quanto maior o nível de representação, de mimesis, mais o ator está empenhado em dar livre vazão ao caminho do personagem e em enfatizar a "ilusão cênica". Para que essa "ilusão cênica" envolva o espectador, o teatro tradicional se reporta a texto, convenções, ilusões e ausência de risco físico: nele, tudo é "simulado", "fingido". Não é sem razão que o teatro de representação é também chamado de "teatro de cultura", precisamente por ter sua criação engendrada pelo texto escrito. A glória desse teatro consiste em encenar "grandes obras", em ser "fiel ao autor".

No teatro de representação, os atores, e até mesmo o diretor, não passam de instrumentos a favor da literatura dramática, não podendo ser considerados, essencialmente, como co-produtores desse discurso. Enquanto o ator "empresta" o seu corpo, voz e emoção para que o personagem "incorpore", o diretor "empresta" a sua mente para o autor, estudando, inclusive, sua biografia com a finalidade de apreender aquilo que podemos definir na seguinte questão: "o que será que o autor quer dizer com esse texto?". Uma questão da Hermenêutica.

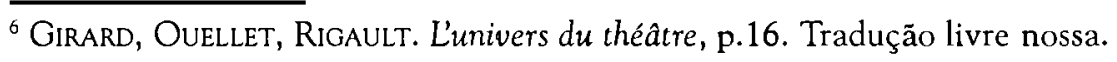


Se tomarmos por seu denotatum o conceito de atuaçāo, veremos que é una ação em que ocorre o exercício da influência ou, em outras palavras, ação com intenção de influenciar o outro. Atuação e retórica estariam, assim, ligadas no processo de significar.

No discurso cênico, entendido aqui como sistema semiótico, sāo redimensionadas como funçōes não só a linguagem no teatro, ${ }^{7}$ mas também o teatro como linguagem. Já vimos que o teatro tradicional considera a representação como o próprio exercício teatral. Lembremos que não é por se utilizar do texto escrito que uma encenação pode ser classificada como "representação". Também na encenação-atuação existe esse uso, mas de uma maneira singular. Se no teatro de representação, como já foi dito, a pergunta formulada pelo diretor era "o que será que o autor quer dizer com esse texto?", no Teatro de Atuação o problema é outro. Em termos do Teatro de Atuação, a criação é fundamentada na ação exercida sobre o espectador: a persuasão. Não que a criação teatral seja em função do espectador como o é, nesse sentido, a criação do discurso publicitário em relação ao consumidor. A persuasão teatral caminha em outra direção. Não se trata de perceber os desejos do espectador e manipulá-los (o teatro de representação exerce melhor essa função), mas, ao contrário, de perceber as necessidades profundas do espectador - ainda que ignoradas ou negadas por ele. Nesse sentido é que a função do texto é singular: ele age como um bisturi que retira o que está escondido em cada um e propicia o encontro entre os criadores envolvidos no processo. Desse encontro, necessariamente sincero, nasce a persuasão. Em outras palavras, a sinceridade produz a persuasāo: o desnudamento do ator, provocado pelo encontro com o texto, serve como instrumento de influência sobre o espectador, para quem e no lugar de quem o ator se revela. Não é a manipulaçāo dos sentidos e das "emoçōes estéticas" do público que o persuade; sāo, antes, as verdades desse encontro. A questão que se coloca, então, para o espectador e para o analista do discurso cênico, está diretamente relacionada a que nos assoma quando vemos, por exemplo, uma cena de violência no nosso dia-a-dia: "por que isso me comove?". E a resposta, tanto nesse caso como no caso do Teatro de Atuação, é a mesma. Porque é verdade, como assegura Grotowski:

Este ato de total desnudação de um ser transforma-se numa doação do eu que atinge os limites da transgressão das barreiras e do amor. Chamo isso um ato total. Se o ator age desta maneira, transforma-se numa espécie de provocação para o espectador. [O teatro] proporciona uma oportunidade que poderia ser chamada de integração, de um tirar de máscaras, de uma revelação da substância autêntica: uma totalidade de reaçōes físicas e mentais. (...) É verdade que o ator executa essa ação, mas só pode executá-la através de um encontro com o espectador (...), num confronto direto com ele e, de certa forma, "em lugar dele".

\section{SEM INTENÇĀO DE ENGANAR: A SINCERIDADE DO ATOR}

O Método Grotowski - que, doravante, será grafado MG - de criação cênica parte do total desnudamento do ator, ou seja, do ator em "estado de sinceridade".

\footnotetext{
${ }^{3} \mathrm{E}$, nesse sentido, internas ao universo representado: o discurso é dirigido de um personagem a outro e as funções dizem respeito a essa interlocução, ainda que Ingarden admita que duas delas a comunicaçāo e a persuasão - dirijam-se também ao espectador. No entanto, para ele, mesmo a influência exercida sobre o espectador é de ordem estética: "consiste em suscitar nele a vivência estética e a emoção que lhe causam os destinos humanos representados". INGARDEN. p.161.

${ }^{8}$ Grotowski. Em busca de um teatro pobre, p.211.
} 
Para este filósofo teatral, o teatro não pode ser um fim em si mesmo. Seu objetivo, assim como da música ou da dança para os derviches, é sagrado: o teatro é um veículo, um meio de auto-estudo, de auto-exploração. De acordo com Grotowski, o ator tem, em si mesmo, seu campo de trabalho e ferramenta de exploração: a mão, o olho, a orelha, o coração são, ao mesmo tempo, o material a ser estudado e instrumento. A interpretação, vista desse modo, é o trabalho de uma vida, sendo que o ator amplia, através das penosas e sempre cambiantes circunstâncias dos ensaios, seu conhecimento de si mesmo. $\mathrm{Na}$ terminologia de Grotowski, o ator permite que o papel o penetre. Nessa tarefa, seu grande obstáculo é a sua própria pessoa. No entanto, através de um constante trabalho, o ator adquire um domínio técnico sobre seus meios físicos e psíquicos e, por meio dele, derruba as barreiras emocionais e corporais que impedem a sua entrega: o deixar-se penetrar pelo papel está relacionado com a própria exposição do ator que não vacila em mostrarse exatamente como é. $\mathrm{O}$ ato de interpretar é um ritual de sacrifício - seu presente ao espectador - daquilo que a maioria dos homens prefere ocultar: as próprias máscaras e segredos. Entre o ator e o público existe uma relação similar à que se dá entre sacerdote e fiel. O sacerdote celebra o rito para e em nome dos demais e os atores, para Grotowski, oferecem sua representaçāo como uma cerimônia para quem deseja assistir. $\mathrm{O}$ ator invoca e deixa desnudo o que existe em todo homem e que é encoberto pela vida cotidiana. $O$ teatro é sagrado porque o objetivo é sagrado: ocupa um lugar claramente definido na comunidade e responde a uma necessidade que as igrejas já não podem satisfazer. Tornar visivel aquilo que é invisível: dizer, através dos ritos, coisas interditas. ${ }^{9}$ Como o ator pode fingir e, ao mesmo tempo, trazer sinceridade à sua interpretação? A condição de sinceridade estabelecida por Grotowski é sine qua non para a realização da ação teatral. Por esse caminho, pensamos ser possível chegar aos mecanismos utilizados pelo discurso cênico para veicular atos de fala sérios.

Através dos atos de fala - que, segundo Searle, podem ser assertivos (se queremos dizer às pessoas "como as coisas são"), diretivos (quando tentamos levá-las a fazer alguma coisa), compromissivos (quando nos comprometemos a fazer algo), expressivos (se os utilizamos para "expressar nossos sentimentos e atitudes") e declarativos (quando podemos provocar mudanças no estado de coisas através da emissão de sentenças) produzidos em cena, podemos alcançar o propósito ilocucionário e a intencionalidade do(s) sujeito(s) produtor(es) do discurso na medida em que um sujeito, por meio dos atos ilocucionários, atua sobre os outros com determinada finalidade intencional, ou seja, para influenciá-los de alguma maneira, utilizando para isso certas estratégias discursivas. No caso do discurso cênico, são estabelecidas convenções que permitem ao sujeito comunicante atuar sobre o espectador através do jogo lúdico que envolve estratégias várias, como a sedução e a provocação.

\section{O ATOR É UM FINGIDOR?}

Otor finge ser alguém que ele realmente não é, finge realizar os atos de fala e outros atos desse personagem. (...) uma peça, isto é, uma peça encenada, não é uma representação fingida de um estado de coisas, mas o próprio estado de coisas fingido, já que os atores fingem ser os personagens. Nesse sentido, o autor da peça,

\footnotetext{
${ }^{9}$ Brook. El espacio vacío, p.75-7.
} 
de modo geral, não finge fazer asserções; ele dá instruções sobre como fingir, que os atores então seguem. (...) parece-me que a força ilocucionária do texto de uma peça é como a força ilocucionária de uma receita de bolo. O elemento de fingimento intervém no nível da encenação. ${ }^{10}$

Sabemos que fingir é um verbo intencional já que ninguém finge fazer alguma coisa sem ter essa intenção. A intenção ilocucionária do autor é que define uma obra como sendo de ficção: as emissōes realizadas no discurso sério não são diferenciadas daquelas realizadas no discurso ficcional senão pela intenção de invocar as convenções horizontais, já que fingimos realizar atos ilocucionários por meio da emissão real de sentenças. Em outras palavras, o elemento constitutivo dos atos ilocucionários fingidos é a realização efetiva do ato de emissão com a intenção de estabelecer a ficção, ou seja, de invocar as convenções horizontais que a instituem. Quando falamos de "fingimento", estamos nos referindo ao que está presente na ficção, sendo bastante distinto da mentira.

Na mentira, existe a intenção de enganar, enquanto na ficção é estabelecido um pacto entre os interlocutores: o alocutário sabe que está diante de uma obra ficcional. No teatro, é estabelecido o espaço do ficcional. No caso do discurso teatral, o espectador sabe que está diante de uma encenação - que é o locus de um discurso cênico visual e sonoro, realizado a partir de um texto e através de diversas materializações (atores, cenário, figurino, iluminação, etc). Quando um indivíduo vai a uma sala assistir a um espetáculo, ele adere às convenções horizontais: é instituído o espaço do "fingimento", da ilusão. "A 'caixa' teatral, o jogo, trazem em si mesmos, a situação artificial". " Como se dá, então, o processo do fingimento e a imbricação deste com a condição de sinceridade postulada por Grotowski?

$\mathrm{Na}$ maioria das encenações teatrais, o diretor, tendo como base o "roteiro" estabelecido pelo texto, trabalha com os atores a melhor maneira de se fingir as situaçōes apresentadas. $O$ intuito é atingir o propósito norteador da encenação, que se desdobra em diversos efeitos dirigidos à platéia. Normalmente o encenador deseja atingir o público de determinada maneira e deseja vê-lo reagir. É comum, no meio teatral, se ouvir frases como "a platéia estava fria" ou "hoje a intenção X funcionou". Essas frases explicitam a visão da ação teatral como uma ação com intenção de influenciar o outro. Uma platéia estar fria significa que os efeitos esperados não foram atingidos e quando um ator diz que sua intenção $X$ funcionou significa dizer que o efeito pretendido foi atingido, seja fazendo a platéia rir ou se emocionar.

Numa encenação teatral, temos um emaranhado de intencionalidades em jogo: do autor que, ao escrever o texto, possuía uma certa finalidade; do encenador que, ao escolher um texto e não outro, satisfaz a determinadas intenções e, até mesmo, do ator que, ao interpretar seu papel, carrega-o de intenções próprias. Todos esses componentes intencionais individuais trabalham em função de uma intencionalidade coletiva, da qual resulta o espetáculo. ${ }^{12}$ Nessa rede de intenções, está presente a pergunta já citada anteriormente: "o que o autor quer dizer?".

\footnotetext{
${ }^{10}$ SeARle. Expressão e significado, p.111. Grifos nossos.

"Demarcy. Semiologia do teatro, p.26.

12 Conforme Searle, "a relação do componente singular ao componente coletivo da intenção é (...) a mesma da relação que se instaura entre a representação dos meios e dos fins nas intenções individuais. O componente individual é o meio para se chegar ao fim coletivo". SeArle. Lintencionnalité collective, p.243. Traduçăo nossa.
} 
O autor indica através de rubricas (indicações presentes no texto) como deve ser construída a ação dramática. Ao diretor, cabe decidir seguir ou não essas indicações. Nesse ponto é que entram suas intençōes em relação ao texto — o tratamento dado à obra pode alterar completamente a finalidade intencional primeira do autor. Ao ator cabe, a partir da direção tomada pelo encenador, construir seu personagem no qual se mesclam, às intenções próprias, aquelas determinadas pelo diretor. $O$ ator em cena funciona, desta maneira, como uma espécie de "porta-voz" dessa intencionalidade coletiva e é através do seu olhar que o espectador vê os acontecimentos encenados. Nesse sentido, a expressāo teatral é inseparável daquele que a efetua não tendo, o espectador, como analisar a manifestação artística em si mesma (ao contrário do leitor). A única maneira através da qual ele pode determinar o texto de uma história é pelo modo como ela é contada.

Com qual finalidade, entāo, realiza-se a montagem de um espetáculo? Para Grotowski, a encenação não serve para "ilustrar" um texto ou contar uma história (esse seria um tratamento literário, não teatral): "o espectador talvez fique contente. (...) Mas não estamos no teatro para agradar ou alcovitar o espectador. Estamos ali para dizer-lhe a verdade". ${ }^{13}$ Segundo ele, a criação teatral parte de uma necessidade do diretor - e dos atores - de dizer alguma coisa e o texto serve aqui como uma ponte para atingir o objetivo primeiro, não sendo ele a finalidade da encenação.

Gostaríamos de reiterar que, em se tratando de linguagem teatral, consideramos "texto" o discurso verbal contido em uma determinada montagem teatral, no momento de sua representaçāo e inserido no dispositivo cênico, ou seja, numa determinada miseen-scène. O texto é tratado levando-se em conta seu aspecto lingüístico (discursivo) e extralingüístico (situacional). Voltando à questão da finalidade, podemos dizer que o comprometimento que ocorre durante o curso de uma representação não é com a verdade do que está sendo dito, mas com a verdade do que está sendo, implicitamente, dito no texto: o sujeito comunicante, por meio de atos ilocucionários fingidos, emite suas crenças sobre o mundo e expressa uma atitude perante ele. Nessa perspectiva, o texto funciona como uma parábola de uma realidade que o sujeito percebe como uma verdade necessária para o espectador, como um conhecimento que ele persegue para si e para o outro. Em outras palavras, o processo do fingimento parte da necessidade do locutor de dizer algo ao alocutário que ele considera verdadeiro e necessário. Essa forma indireta da ação teatral não seria o que, na linguagem ordinária, chamamos de metáforas? Nos termos da Teoria dos Atos de Fala, podemos dizer que o locutor realiza atos de fala indiretos na medida em que um "ato ilocucionário é realizado indiretamente através da realização de um outro". 14

\section{Metáfora teatral e significaçāo}

O problema da metáfora pode ser concentrado no seguinte conjunto de questões que nos interessa diretamente: o que podemos entender por "metáfora teatral"? Como se dá a produção da metáfora teatral e sua compreensão pelo espectador? De que modo podemos diferenciar as metáforas presentes no discurso cênico das metáforas que constituem o próprio discurso?

${ }^{13}$ Grotowski. Em busca de um teatro pobre, p. 195.

${ }^{14}$ Searle. Expressão e significado, p.49. 
Para que possamos responder às duas primeiras questōes - mais complexas e difíceis -, é necessário delimitar as metáforas presentes no nível ficcional do discurso cênico. Para isso, vamos resgatar um exemplo dramatúrgico citado por Searle: ${ }^{15}$ "Julieta é o sol" (fala de Romeu na peça Romeu e Julieta, de W. Shakespeare). De acordo com algumas análises como, por exemplo, a de Cavell, citado por Searle, ${ }^{16}$ Romeu quer significar que o seu dia começa com Julieta. Além dessa interpretação, podemos, sem sermos absurdos, dizer que Romeu quer significar que Julieta é ardente ou que ela governa as suas horas. Obviamente, nenhuma metáfora como essa nos levaria a pensar que Romeu quer significar que Julieta é um astro de temperatura tão elevada que, ao aproximar-se dela, ele sofreria, literalmente, queimaduras de terceiro grau. Podemos notar, em nossa exposição, vários dos aspectos discutidos por Searle: essa metáfora, como a grande maioria, é aberta a várias interpretaçōes. Ao mesmo tempo, certas interpretaçōes não são possíveis por não fazerem parte do sistema de princípios compartilhado pelo falante e pelo ouvinte. Além disso, não há nada em "Julieta é o sol" que convencione o significado de "Meu dia começa com Julieta" ou quaisquer outros significados. Eis o funcionamento das metáforas em geral.

O que, então, nessa metáfora, nos permite pensar que ela pertence ao contexto ficcional de um discurso cênico? Em primeiro lugar, o nosso conhecimento de que ela pertence a uma obra literária e, porquanto, ficcional. Em segundo lugar - e mais importante - , pelo fato de que todas as interpretaçōes possíveis dizem respeito ao contexto ficcional da peça e ao que, dentro dele, Romeu quis significar. O que queremos dizer com isso? A metáfora teatral, ao contrário da metáfora presente no discurso cênico, parece não ter relação com o que o personagem ou autor quer significar com ela. $\mathrm{Ou}$ seja, podemos dizer que a metáfora ficcional é interpretada a partir do significado intencional do personagem, enquanto a metáfora teatral, cuja interpretação é muito mais sutil e complexa, está relacionada com a intenção do ator. Como, então, funciona a metáfora teatral?

Suponhamos que um diretor que trabalhe com o MG resolva, juntamente com os seus atores, montar Romeu e Julieta. A escolha do texto, nesse tipo de encenação, não parte do desejo de montar uma peça clássica, cuja história tenha um sucesso garantido junto ao público, e da qual os personagens sejam um "desafio" para os atores. Mas parte da intenção do encenador e dos atores de entregar ao público uma "verdade" amorosa, de abrir o próprio coração e se confessar numa espécie de declaração de amor. ${ }^{17}$ Essa intenção é mostrada através do texto ou, simplesmente, das imagens do texto, de signos. A relação do grupo com, no caso, a obra literária, é similar ao testemunho verídico situação que, provavelmente, todos nós já vivenciamos — de uma relação amorosa.

O texto passa a ser vivenciado afetivamente. E aí as relaçōes de prazer e/ou gozo de que nos fala R. Barthes sāo cabíveis de serem pensadas. Da mesma maneira que o

\footnotetext{
is SeARLE. Expressão e significado, p. 149.

${ }^{16}$ IBIDEM. p. 149.

${ }^{17}$ Em Auchlin, podemos ver a dificuldade para o analista do discurso de ter acesso a uma genuína declaração de amor. E isso, é claro, será possível desde que ele seja um dos interlocutores ou um voyeur. No Teatro de Atuação, o espectador tem a oportunidade de assumir qualquer dos dois papéis: o ator confessa a ele, espectador do seu drama - e, nesse sentido, voyeur - e o faz seu interlocutor porque entrega para o público sua própria relação amorosa.
} 
texto nos comove, comove também aos atores quando os toca no nó das emoções humanas. Vamos supor, ainda, que dois dos atores sejam casados e que as palavras de Romeu e de Julieta caibam neles como uma luva: eles já as falaram de outro modo. $\mathrm{O}$ que, então, através das metáforas do texto, eles dizem um para o outro? Que confissão é essa que o público, obsceno, presencia? Quando o ator - que faz Romeu - fala para a atriz - que faz Julieta - "Julieta é o sol", ele está falando dela, sua mulher: "Maria é o sol”, scja lá o que ele tenha pretendido significar com isso. E a entrega (para o público) se dá mesmo que cles não sejam casados e que ele não esteja falando da atriz com a qual contracena, mas de uma outra mulher que significou para cle uma metáfora da qual a paráfrase seria a mesma dessa.

Entretanto, uma metáfora, por ser fruto da intenção de um falante, é produzida por ele. Ela serve para significar aquilo que ele não consegue dizer de outra forma. Para o ator colocar seu significado intencional $\mathrm{em}$ um texto produzido por outra pessoa, ele se utiliza de qual mecanismo?

A nossa visão é de que, a partir dos estímulos produzidos pelo texto, o ator busque imagens - fortes e de suma importância para ele — relacionadas com sua vida pessoal e, através da presença dessas imagens no momento da atuação em cena, ele produza o significado intencional. O texto dramatúrgico, desse modo, passa a ser suporte, ou seja, a sentença literal sobre a qual o ator constrói sua metáfora. Se não houver a intenção do diretor e do ator de transformar o texto do autor em uma metáfora teatral, ele será simplesmente um texto ficcional, uma obra literária a ser representada no palco. É nesse sentido que o texto literário pertence ao universo da ficção. Se o diretor e o ator percebem a multiplicidade de sentidos da peça, eles a transformam em uma metáfora cujos sentidos se transformam naquele intencionado por eles.

Muitas vezes, o encontro do texto com os criadores do discurso cênico se dá de outro modo: o texto já traz, de algum modo, um processo de significação. Ele vai de encontro à necessidade do diretor e do ator de dizer determinada "verdade" ao espectador e, nesse caso, é necessariamente ao contexto da peça que essa significação pertence. Trata-se aqui realizar um ato de fala sério através dos atos de fala presentes no texto literário, ou seja, de realizar um ato de fala indireto.

A produção do ato de fala indireto está intrinsecamente relacionada com a intenção do falante de produzi-lo. No caso do discurso cênico, o ato é produzido de maneira similar: o ator, ao enunciar uma fala do seu personagem, quer significar, como personagem, o que o significado sentencial do enunciado diz e, ao mesmo tempo, quer significar, como ator e em relação ao espectador, uma outra coisa - um significado intencional adicional ao primeiro. Tomemos um exemplo. Em Amor de Dom Perlimplim, o ator (Lenine Martins) que interpreta Dom Perlimplim diz à atriz (Mariana Muniz) que interpreta a esposa do aristocrata: "Perlimplim - Mas já estou fora do mundo e da moral ridícula das pessoas. Adeus". ${ }^{18}$

Ao emitir, em cena, a sentença acima, o ator veicula o significado sentencial do enunciado que, no contexto ficcional, é dirigido à esposa de Dom Perlimplim (c, possivelmente, aos espanhóis contemporâneos de García Lorca). Ao mesmo tempo, ele

is Todos os exemplos utilizados foram retirados de LoRCA. Amor de Dom Perlimplim com Belisa em seu jardim, 1979. 
significa uma outra coisa, esta relacionada com a própria intenção em relaçāo ao público. Nesse momento, podemos inferir que o ator (Lenine Martins) significa também: "ATOR - Sugiro que vocês, espectadores, aproveitem a deixa para refletirem sobre a sua própria moral que, se correspondente à moral dos espanhóis a quem García Lorca se refere indiretamente através desse texto, scrá tāo ridícula quanto a deles".

Como é possível, para o espectador ou para o analista do discurso cênico, inferir um outro significado como esse a partir da sentença emitida? Em primeiro lugar, porque o significado adicional intencionado pelo ator está diretamente em relação com o significado sentencial. Em segundo lugar - e não menos importante —, está o fato de que, pela sentença ser veiculada em cena, é permitido ao espectador se colocar diante da presença física do ator e este, através de mecanismos próprios da linguagem teatral como, por exemplo, entonaçōes e olhares -, deixa perceptível a sua significação intencional.

Enquanto no teatro de representação o ator veicula a intenção do personagem ou, até mesmo, a intenção do autor, no Teatro de Atuação a intenção veiculada por ele e através da fala do personagem pertence ao ator. Ou seja, a intenção veiculada aqui não é a do autor (a "mensagem" do texto), mas o do ator, que nasce da sua necessidade de dizer algo ao espectador, através da realização da elocuçāo fingida produzida pelo autor. Assim, podemos dizer que o funcionamento do discurso cênico como metáfora ou como ato de fala depende da intenção do diretor e dos atores ao produzi-lo.

Do mesmo modo que na intencionalidade coletiva temos os componentes individuais, na encenação teatral, as várias necessidades individuais são integrantes de uma única necessidade coletiva. No espetáculo Amor de Dom Perlimplim, temos a direção (Bete Penido) que escolheu montar esse texto por razões pessoais: podemos supor, por exemplo, que cla gostaria de explicitar a hipocrisia e o machismo da sociedade brasileira ou questionar a moral reinante. Ao seu lado, temos quatro atores que interpretam os personagens da peça e que também têm suas razōes pessoais para trabalharem os próprios medos e barreiras - que poderiam impedir o fluxo de criação - e investirem suas emoções e corpos na construçāo desse discurso coletivo.

Se desejamos, na verdade, pesquisar profundamente dentro da nossa consciência e do nosso comportamento, c atingir (...) seu motor secreto, entāo o sistema integral de símbolos construído na montagem deve apelar para a nossa experiência, para a realidade que nos surpreendeu e nos modelou, para esta linguagem de gestos, murmúrios, sons e entonaçōes extraída das ruas, dos trabalhos, dos cafés - en suma, de todo comportamento humano que tenha deixado uma impressão em nós. ${ }^{19}$

Cada ator busca em sua própria vivência imagens e relações que reportem à existência de seu personagem e, com a partitura (de ações físicas e intenções) que constrói, traz vida a esse personagem e ao seu discurso, que passa a ser um reflexo discursivo do ator. ${ }^{20}$ Năo que o ator tenha que se identificar com o personagem (seria muito difícil

\footnotetext{
${ }^{19}$ Grotowsk1. Em busca de um teatro pobre, p. 45 .

${ }^{20}$ Por trás do texto escrito pelo autor, o ator imprime a sua visão sobre o mundo e as relações humanas tratadas no espetáculo: subjacente ao texto, existe um subtcxto que, através de elementos lingüísticos e extralingüísticos, como a entonação, o olhar, o gesto, é transmitido ao espectador no decurso da encenação.
} 
para alguém que nunca matou interpretar um assassino), mas deve reconhecer nele características humanas que ele próprio poderia ter. $O$ ator se coloca no lugar do personagem: "se fosse eu, vivendo tal situação, como eu reagiria? Que emoçōes eu teria? Quais seriam os meus impulsos? O que eu seria levado a dizer ou o que me levaria a dizer isso que o personagem diz?". Entretanto, para entendermos como é possível, para o ator, colocar-se no lugar do personagem, é necessário que percebamos como funcionam os mecanismos próprios da linguagem teatral.

\section{NOS BAstidores da linguagem teatral}

Durante o processo de ensaios, o texto é analisado em conjunto pelos atores e pelo diretor, para que todos possam construir os sentidos ali percebidos. $O$ ator parte, então, do princípio de que o texto não é literatura, é um código de ações, um esquema a ser vivificado. A pergunta é: “o que o meu personagem quer nesse momento?". Através do discurso que ele emite, desde o que é dito até o modo como é dito, o ator desvela as razões que movem seu personagem e as estratégias que usa para conseguir seus intentos. Os atores devem analisar seus personagens em sua humanidade, devem perceber o que eles fazem com as palavras.

O homem é muito mais complicado. Quase não acreditamos no que dizemos. Quando uma mulher diz: "Hoje estou triste", em que estará pensando? Talvez quisesse dizer: "Vá embora!", ou ainda: "Estou sozinha". Tem-se de ter consciência do que existe atrás das palavras. (...) Quase sempre o significado mais profundo da nossa reação está escondido. Deve-se saber que a reação autêntica transmitida pelas palavras existe realmente, e não apenas ilustra as palavras. ${ }^{21}$

As ações verbais estão implícitas no texto, são o "para que" é dito algo, não o "por que". Em outras palavras, o personagem pode agredir, ameaçar, seduzir ou persuadir

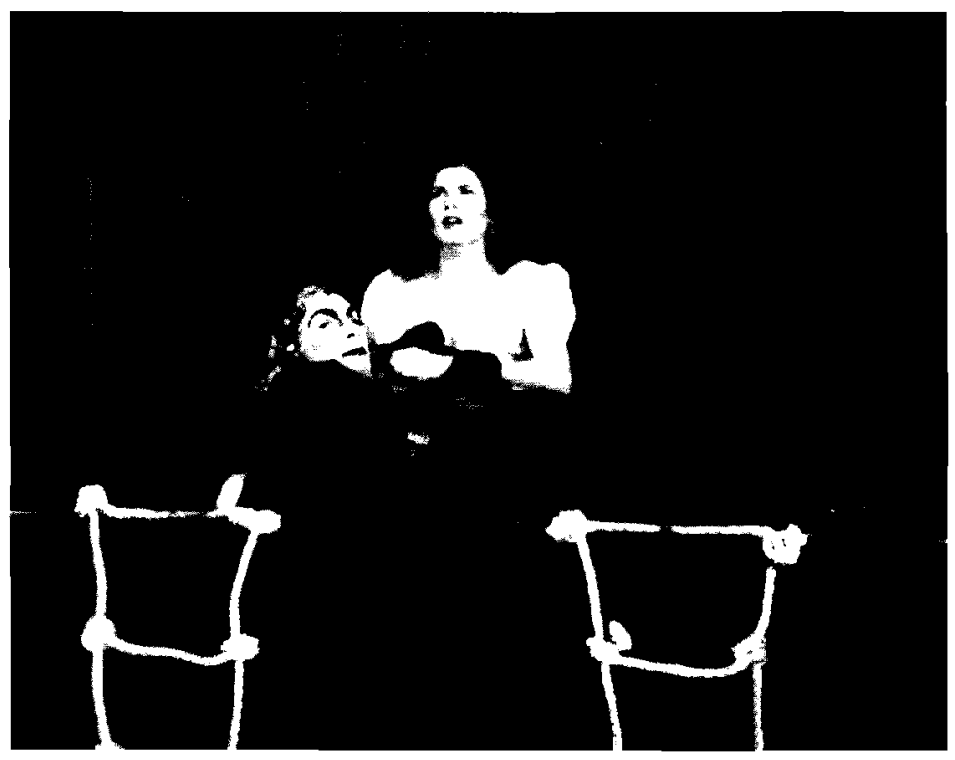

Amor de Dom Perlimplim, Cia. Cínica.

Foto de Evaldo Luna.

${ }^{21}$ Grotowski. Em busca de um teatro pobre, p.194. 


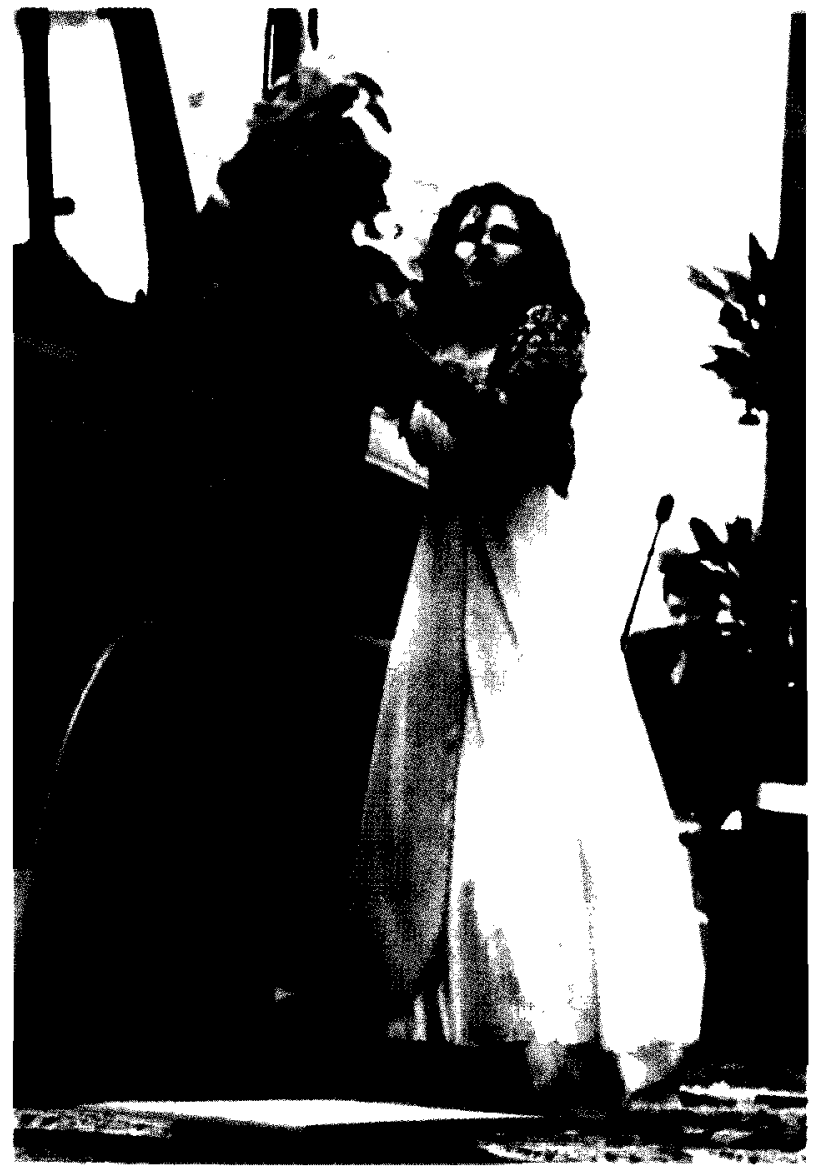

Amor de Dom Perlimplim, Cia. Cínica.

Foto de Evaldo Luna.

com o seu discurso. Cabe ao ator trabalhar essas ações através de vários elementos lingüísticos - como entonação, ênfase, cadência - e corporais - como a gesticulação e outras atitudes corporais. Esse conjunto de elementos compõe as "intenções" trabalhadas no texto.

O discurso do ator no palco é um sistema de signos bastante complexo; veicula quase todos os signos do discurso poético e, além do mais, faz parte da ação dramática. (...) A fala cotidiana é um sistema de inúmeros e diferentes signos. Aquele que fala manifesta seu estado de espírito através daquilo que diz, porém ao mesmo tempo seu discurso (...) é o signo de seu nível cultural e social. Todos esses signos são utilizados pelo (...) ator. (...) A manifestação lingüística de um ator em cena veicula, em geral, vários signos. ${ }^{22}$

O texto de García Lorca, citado anteriormente, trata do casamento de um aristocrata cinqüentão com uma jovem e fogosa donzela. No trecho escolhido, Dom Perlimplim acabou de acordar, na madrugada seguinte à noite de núpcias, e tem em sua cabeça (rubrica) "grandes cornos dourados" - em cena os chifres portados pelo ator causam um efeito patético sobre a platéia que é levada, geralmente, ao riso. Sua esposa, aproveitando-se de seu sono, traiu-o com cinco homens. Através de rubricas, o autor

${ }^{22}$ Bogatyrev. Semiologia do teatro, p.75. Grifos nossos. 
deixa claro que entre os dois não houve relação sexual (Perlimplim, provavelmente, é impotente). Nesse momento ele, desconfiado da traição, a interpela:

Perlimplim - Pela primeira vez em minha vida estou contente! (Aproxima-se e a abraça. Mas nesse instante afasta-se bruscamente dela). Belisa. Quem te beijou? Não mintas, que o sei!

BEIISA (Colhendo o cabelo e pondo-o para frente) - Creio bem que o sabes! Que maridinho tão brincalhão eu tenho! (em voz baixa). Tu! Tu me beijaste!

No trecho escolhido, o objetivo de Perlimplim é descobrir a verdade, enquanto o de Belisa é enganá-lo. Para isso, ela usa a sedução como estratégia. Perlimplim se deixa enganar: ele ama a esposa e deseja que ela o ame também. Para dar coerência a seu personagem, o ator mescla os sentimentos de desconfiança, amor, mágoa e raiva. A atriz torna seu personagem mais humano, mesclando à seduçāo o medo de ser descoberta. É evidente que as intençóes trabalhadas pelos atores variam de intensidade. De maneira similar ao uso ordinário da linguagem, o jogo de intenções - ou de sentidos - é construído no momento da interlocução: além do circuito interno da fala - no qual os interlocutores são os personagens -, a enunciação se processa entre os seres psicossociais - os atores - , que refazem csse jogo a cada apresentação. ${ }^{23}$ Por exemplo, o medo expresso pela atriz varia de acordo com o grau de violência que o ator imprime à sua fala "Não mintas, que o sei!". Do mesmo modo, o grau de desconfiança demonstrado pelo ator orienta o nível de sedução aplicado pela atriz em "Tu! Tu me beijaste!".

A encenação teatral é o palco onde encontram-se as "vozes" dos vários sujeitos implicados. Além do autor, do diretor e dos atores, contribui, ainda, para a construção do sentido no discurso cênico, a dimensão semiótica acontecendo em cada espectador. Nesse espetáculo, a platéia começa a ser enredada na intriga do texto. Dom Perlimplim (nesse momento já esquecemos ${ }^{24}$ do ator e vemos o personagem agir), ciente da traição de sua esposa, arquitetou uma vingança. Ele criou, através de cartas escritas por ele mesmo, um jovem apaixonado e, por meio desse mecanismo sedutor, conseguiu que sua mulher se apaixonasse pelo amante imaginário. A platéia já sabe que alguma coisa estranha está acontecendo. Até o momento, o texto e a encenação conduziram para um mistério com poucas pistas. Existe um plano entre Dom Perlimplim c sua criada Marcolfa; Belisa fala, tendo o público como confidente, de sua paixão pelo jovem. Então, uma carta é atirada pelo balcão e Dom Perlimplim, para conseguir arrancar de sua esposa uma confissão de amor, diz-se conhecedor dos fatos e cúmplice dela. No trecho seguinte, o ator que interpreta Dom Perlimplim constrói diversos efeitos de sentidos intencionalmente dirigidos à platéia:

\footnotetext{
23 Simultancamente à interlocução básica da encenação, a saber, a relação ator-platéia, cxiste uma outra: a situação concreta de troca que ocorre entre os atores no decurso da encenação. No presente trabalho, nos deteremos na relação ator-platéia, sendo a relação entre os atores assunto para uma outra análise.

${ }^{2+}$ Conforme Auchlin, "o processo pelo qual os cstados cnocionais são transmitidos mobiliza o mesmo mecanismo, a saber, uma relação, interna ao organismo, entre percepção do estado e manifestação (extcriorização) dos sintomas deste estado. A sincronização é o signo c o meio desta comunhão. (...) a atribuição por um observador de estados afetivos a um sujeito repousa no mesmo princípio de contágio. Se o analista deve (...) identificar até un certo ponto os estados psicológicos dos participantes das interações que ele estuda, ele deve então reconhecer igualmente que ele cstá implicado nesse processo". Auchun. Modeles de l'interaction verbale, p.229. Tradução nossa.
} 
Perlimplim - Não temas. Há quinze dias vi esse jovem pela primeira vez. Posso dizer-te com toda sinceridade que sua beleza me deslumbrou. Jamais vi um homem en quem o varonil c o delicado se combinassem de maneira tão harmônica. Sem saber por que pensei em ti.

Ao mesmo tempo que o personagem constrói a imagem do jovem apaixonado para sua esposa - Perlimplim busca elementos que impressionarão sua bela e fogosa esposa como a beleza e a masculinidade - o ator a constrói para o público e com o público. "Eu dirijo o meu discurso para um interlocutor: se é um rapaz, busco nele a imagem do jovem que construo para a Belisa. Faço com que ele se sinta o amante de Belisa. Se é uma mulher, construo uma imagem de um jovem que a seduza, busco seduzi-la junto com Belisa". Nesse depoimento, o ator Lenine Martins - que interpreta Dom Perlimplim na montagem citada - explicita alguns dos mecanismos utilizados pela linguagem teatral na construção do duplo espaço de interlocução ocorrido no processo enunciativo.

A cscolha de determinado texto, o tratamento dado à obra e até o projeto gráfico cle um espetáculo fazem parte das estratégias utilizadas para atingir o público-alvo que, no caso do discurso cênico, é de ordem intelectual e afetiva. Aqui, a influência é exercida através do "fazer saber", do "fazer pensar" e do "fazer sentir".

A platéia não é um público qualquer, é um público no mínimo suposto, isto é, o sujeito destinatário é o espectador para o qual é produzido uma determinada "linha" de espetáculo: vai desde a escolha do texto à concepção da mise-en-scène (cenário, figurino, iluminação, marcação de cenas, etc). No caso de Amor de Dom Perlimplim, o sujeito destinatário é composto por um público intelectual, consumidor de teatro e apreciador de clássicos. Para Grotowski, por exemplo, o espectador-alvo não é aquele que vai ao teatro para satisfazer a uma exigência social de "cultura" nem aquele que considera o teatro um entretenimento, uma diversão como passear, ver televisão ou ir a futebol. Ele está interessado no espectador que

sinta uma genuína necessidade espiritual, c que realmente deseje, através de um confronto com a representação, analisar-se. (...) aquele que empreende um processo interminável de autodesenvolvimento, c cuja inquietação não é geral, mas dirigida para uma procura da verdade de si mesmo e da sua missão na vida. ${ }^{25}$

Sabemos que a relação que define o teatro como linguagem é aquela existente entre o ator e a platéia: toda encenação é dirigida a uma platéia. Nem que seja composta por um único espectador. Para que exista teatro, é necessário esse encontro. Durante os ensaios, a platéia (ou sujeito interpretante - TUi —, nos termos de Charaudeau) é o diretor que orienta o sentido do discurso, estando no papel privilegiado de platéia, semiólogo e analista do discurso. Só assim ele tem condiçóes de avaliar os efeitos produzidos pelo processo enunciativo. Nas representações públicas, essa posição é ocupada pelas pessoas comuns que formam o público do teatro: o espectador com quem o ator estabelece uma cumplicidade.

Para Grotowski, o teatro prescinde de todos os outros elementos que o compōem: cenário, figurino, iluminação, trilha e até mesmo do texto. Imprescindível ao teatro é a ação e a reação, o ator e o espectador e a situação de troca aos quais se resume o Teatro Pobre:

\footnotetext{
${ }^{25}$ Grotowski. Em busca de um teatro pobre, p. 35 .
} 
um teatro ascético no qual os atores $\mathrm{c}$ os espectadores são tudo o que existe. Todos os outros elementos (...) sāo construídos através do corpo do ator. (...) Isso não significa que não empreguemos a literatura, mas sim que não a consideramos a parte criativa do teatro. (...) Já que o nosso teatro consiste somente de atores e espectadores, fazemos exigências especiais a ambas as partes. Embora não possamos educar os espectadores (...) podemos educar o ator. ${ }^{20}$

\section{O contrato estratégico}

O contrato realizado entre ator e platéia constitui-se de um ritual sociolinguageiro construído pelo conjunto de restriçōes que codificam as práticas linguageiras e é em relação a cle que podemos analisar estratégias e contratos encenados pelos sujeitos. No caso da encenação teatral, o "contrato de fala" estabelece que o ator detém a fala e que ao espectador cabe receber o conteúdo transmitido e reagir a ele, não se manifestando verbalmente. A fala pode ser permitida ao espectador em determinadas linhas de espetáculo, ditas interativas, mas, mesmo nesse caso, são "dirigidas" pelo ator em cena. Cada linha de pensamento sobre o teatro tem um objetivo ou conteúdo a transmitir. $\mathrm{O}$ teatro pode pretender divertir, ensinar ou, na acepção de Grotowski, dizer a verdade ao espectador, e, para cada finalidade, são usadas determinadas estratégias. No entanto, podemos notar que a linguagem teatral trabalha, sobremaneira, com as emoções do espectador. Para Grotowski,

a representação do ator - afastando as meias medidas, revelando-se, abrindo-se, emergindo de si mesmo, em oposição ao fechamento - é um convite ao espectador. Esse ato deve ser comparado (...) a um amor genuíno entre dois seres humanos. (...) Este ato de total desnudação de um ser transforma-se numa doação do eu que atinge os limites da transgressão das barreiras e do amor. Chamo isto um ato total. Se o ator age dessa maneira, transforma-se numa espécie de provocação para o espectador. (...) Ele faz isso para o espectador? A expressão "para o cspectador" implica (...) numa barganha consigo mesmo. Devemos dizer "em relação ao" espectador ou, talvez, em lugar dele. É precisanente aqui que está a provocação. ${ }^{27}$

O teatro mostra-se, assim, como verdadeiro espetáculo semiótico, tanto como prática de escritura quanto como prática de cena. Daí seu caráter heterogêneo. Todas as teorias que tentaram e tentam elaborar o teatro e o tomam como objeto de escritura dramática ou como mise-en-scène têm se esquivado ao trabalho com a linguagem, no sentido dos processos enunciativos. Nossa reflexão tratou somente de ser uma introdução, um apontamento para os estudos de uma Semiótica do Teatro, em que a Análise do Discurso contribuiria com uma cartografia desse território tão pouco explorado. 


\section{RÉ SUMÉ}

Cet article présente un propos de lecture qui a comme base les principes théoriques de l'Analyse du Discours et de la Sémiotique Théâtral. Il part de la distinction entre théâtre, littérature dramatique e théoric théâtral et il voit comme sujet de la Critique Théâtral, par son étroite relation avec la littérature, ce que nous appelons littérature dramatique. Le théâtre de Grotowski est vu comme un concept en scène, dans la relation entre l'acteur et le spectateur, soit mediatisée - ou non - par le texte. À partir de la discussion proposée par Searle sur l'estatut logique du discours ficcional, deux importants concepts sont définis: - le concept de théâtre de représentation et le concept de théâtre d'action.

\section{MOTS-CLÉS}

analyse du discours et théâtre, mise-en-scène et signification

\section{REFERÊNCIAS BIBLIOGRÁFICAS}

Artaud, A. O teatro e seu duplo. São Paulo: Max Limonad, 1987.

Artaud, A. Linguagem e vida. São Paulo: Perspectiva, 1995.

Auchlin, A. Le bonheur conversationnel: émotion e cognition dans le discours et l'analyse du discours. In: Véronique, D., Vion, R. Modeles de l'interaction verbale. Aix-en-Provence, 1995.

Bogatyrev, P. Os signos do teatro. In: Semiologia do Teatro. São Paulo: Perspectiva, 1988.

Brook, P. El espacio vacio: arte e técnica del teatro. Barcelona: Ediciones Peninsula, 1998.

Demarcy, R. A leitura transversal. In: Semiologia do Teatro. São Paulo: Perspectiva, 1988.

Girard, G., Ouellet, R., Rigault, C. Lunivers du théâtre. Tunis: Cèrés Éditions, 1997.

Grotowski, J. Em busca de um teatro pobre. Rio de Janeiro: Civilização Brasileira, 1992.

Lorca, E. G. Amor de Dom Perlimplim com Belisa em seu jardim. São Paulo: Martins Fontes, 1979.

Ryngaert, J. P. Ler o teatro contemporâneo. São Paulo: Martins Fontes, 1998.

Searle, J. R. Expressão e Significado: estudos da teoria dos atos de fala. São Paulo: Martins Fontes, 1995.

Searle, J. R. Les actes de langage. Paris: Hermann, 1972.

SeArle, J. R. L'intentionnalité collective. In: La communauté en paroles: communication, consensus, ruptures. Bruxelles: Mardaga, [s.d.]. 